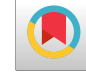

\title{
Liver Injury Induced by the Interaction Between Fluoxetine and Celecoxib: A Case Report and the Literature Review
}

\author{
Hong-Mei Zhang ${ }^{1}$, Guang-Chen Liu ${ }^{2}$, Yang-Fang $\mathrm{He}^{3}$, Wei Zhou ${ }^{1,{ }^{*}}$ and Ji-Qiu Hou ${ }^{4, * *}$ \\ ${ }^{1}$ Department of Pharmacy, The First Hospital of Jilin University, Changchun, China \\ ${ }^{2}$ Department of Orthopedics, The Affiliated Wuxi No. 2 People's Hospital of Nanjing Medical University, Wuxi, China \\ ${ }^{3}$ Department of Endocrinology and Metabolism, The Second Hospital of Jilin University, Changchun, China \\ ${ }^{4}$ Department of Pharmacy, The Second Hospital of Jilin University, Changchun, China \\ "Corresponding author: Department of Pharmacy, The First Hospital of Jilin University, 71 Xinmin Ave., Changchun, Jilin Province, China. Tel: +86-43184808124, Email: \\ redflower_999@126.com \\ ${ }^{* *}$ Corresponding author: Department of Pharmacy, The Second Hospital of Jilin University, No. 218 Ziqiang St., Nanguan District, Changchun, Jilin Province, 130041, China. Tel: \\ +86-43184808124, Fax: +86-43188796397, Email: autumn0207@163.com
}

Received 2019 May 10; Revised 2019 August 26; Accepted 2019 August 26.

\begin{abstract}
Introduction: Fluoxetine is used commonly as an antidepressant and celecoxib is widely used for pain relief and reducing inflammation in various chronic conditions. Both of them can cause liver injury, but it is a rare adverse reaction of their interactions. Here we report a case of liver injury possibly induced by fluoxetine and celecoxib in a female patient.

Case Presentation: A 55-year-old woman who was given fluoxetine for three months and celecoxib for seven days was transferred to the Department of Emergency, the first affiliated hospital of Jilin University, Changchun, China, on March 2019, with icterus on the skin, dark brown urine and pain in the upper abdomen. Alanine aminotransferase (ALT) and Aspartate aminotransferase (AST) levels were elevated. According to follow-up examination, liver injury and cholecystitis were diagnosed. After discontinuing the two drugs and starting symptomatic treatment, her ALT and AST levels returned to normal.

Conclusions: The mechanism of liver injury induced by fluoxetine and celecoxib remains unclear. Inhibitors and substrates of CYP2D6, CYP2C9, CYP3A4, and CYP2C19 might participate in this situation. The interaction between fluoxetine and celecoxib, as well as other inhibitors and substrates with similar metabolic pathways, are noteworthy.
\end{abstract}

Keywords: Adverse Drug Reactions, Alanine Transaminase, Aspartate Aminotransferases, CYP2C19 Protein, Celecoxib, China, Fluoxetine, Human, Injury, Liver

\section{Introduction}

Fluoxetine is a selective inhibitor of neuronal serotonin uptake carrier, it can inhibit the reuptake of serotonin by the serotonin reuptake transporter, thereby enhancing and prolonging the serotonin signaling (1). Fluoxetine is used commonly as an antidepressant but it is also indicated for other psychiatric disorders such as obsessivecompulsive disorder or bulimia nervosa (2). Though fluoxetine is well tolerated by most patients, it still can produce a series of side effects of different degrees, such as neurological problems (dizziness, headache, sleeplessness, depression, thrillingness), digestive system problems (nausea, emesis, diarrhea and constipation), palpitation, leukopenia, sex disorder, bipolar affective disorder, low serum sodium, and organ failure (liver, renal) in rare cases $(3,4)$.

Celecoxib is a nonsteroidal anti-inflammatory drug (NSAID) which can selectively inhibit cyclooxygenase-2 (COX-2) and prevent the converting of arachidonic acid to prostaglandin precursors. It is widely used for pain relief and reducing inflammation in various chronic conditions such as osteoarthritis, rheumatoid arthritis, and ankylosing spondylitis (5). Although celecoxib is usually a welltolerated drug, it is not harmless. It has several side effects such as thrombocytopenia, renal side effects, gastrointestinal bleeding, ulceration, and perforation $(6,7)$.

Though liver injury induced by fluoxetine (Table 1 ) or celecoxib (Table 2) has been reported, there are no reports on liver injury caused by their interaction, so this report can be used to warn and guide the clinical use of fluoxetine and celecoxib. Accordingly, we report a case of liver injury caused by both fluoxetine and celecoxib in an adult female.

\section{Case Presentation}

A 55-year-old woman was sent to the Department of emergency, the first affiliated hospital of Jilin University, Changchun, China presented with icterus on the skin, dark-brown colored urine and upper abdominal pain in March 2019 (Figure 1). She was recently diagnosed with de- 


\begin{tabular}{|c|c|c|c|c|c|c|c|c|c|}
\hline Author & Age, $y /$ Sex & Country/Cit & & Diagnosis & Clinical Characte & ristics & ALT, IU/L & Therapy & Prognosis \\
\hline $\begin{array}{l}\text { Johnston and Wheeler } \\
\text { (8) }\end{array}$ & $35 / \mathrm{M}$ & America/Albuqu & rque & Chronic hepatitis & Fatigue & & 156 & Discontinued & Normal \\
\hline Agrawal et al. (9) & $41 / F$ & America/Chica & & DILI & Jaundice & & 1613 & Discontinued & Normal \\
\hline Cai et al. (10) & 39/M & America/Marsh & eld & Acute hepatitis & $\begin{array}{l}\text { Sharp pain in the } \\
\text { upper quadran } \\
\text { abdomen, jaun }\end{array}$ & $\begin{array}{l}\text { right } \\
\text { tof } \\
\text { dice }\end{array}$ & 272 & Discontinued & Normal \\
\hline Cai et al. (10) & $45 / \mathrm{F}$ & America/Marsh & eld & Acute hepatitis & $\begin{array}{r}\text { Severe pain in the } \\
\text { upper quadran } \\
\text { abdomen, anor } \\
\text { jaundice }\end{array}$ & $\begin{array}{l}\text { right } \\
\text { t of } \\
\text { exia, }\end{array}$ & 641 & Discontinued & Normal \\
\hline \multicolumn{10}{|c|}{ Abbreviations: DILI, Idiosyncratic drug-induced liver injury; F, female; M, male. } \\
\hline Author & Age, $y / \operatorname{sex}$ & Country/City & & Diagnosis & $\begin{array}{c}\text { Clinical } \\
\text { Characteristics }\end{array}$ & ALT, IU/L & \multicolumn{2}{|c|}{ Therapy } & Prognosis \\
\hline Grieco et al. (11) & $41 / \mathrm{M}$ & Rome/Italy & Chole & estatic hepatitis & $\begin{array}{l}\text { Stomach pains, } \\
\text { nausea, discomfort, } \\
\text { itching, jaundice, } \\
\text { dark urine, pale } \\
\text { feces }\end{array}$ & 234 & \multicolumn{2}{|c|}{ Discontinued } & Normal \\
\hline $\begin{array}{l}\text { Nachimuthu et al. } \\
\text { (6) }\end{array}$ & $67 / \mathrm{F}$ & USA/New York & $\begin{array}{l}\text { Acute } \\
\text { and }\end{array}$ & $\begin{array}{l}\text { hepatocellular } \\
\text { cholestatic liver } \\
\text { injury }\end{array}$ & $\begin{array}{l}\text { Severe right upper } \\
\text { abdominal pain, } \\
\text { nausea, vomiting, } \\
\text { icterus, and loss of } \\
\text { appetite }\end{array}$ & 603 & \multicolumn{2}{|c|}{ Discontinued } & Normal \\
\hline Galan et al. (12) & $55 / \mathrm{F}$ & USA/Royal Oak & Chole & estatic hepatitis & $\begin{array}{l}\text { Jaundice, malaise, } \\
\text { and pruritic rash }\end{array}$ & 261.9 & \multicolumn{2}{|c|}{ Discontinued } & Normal \\
\hline Alegria et al. (13) & 49/M & Portugal/Carnaxide & & $\begin{array}{l}\text { ronic hepatic } \\
\text { disease }\end{array}$ & $\begin{array}{l}\text { Jaundice, fatigue, } \\
\text { and choluria }\end{array}$ & 49 & \multicolumn{2}{|c|}{ Discontinued } & Normal \\
\hline El Hajj et al. (14) & $55 / \mathrm{F}$ & $\begin{array}{l}\text { United States } \\
\text { /Pittsburgh }\end{array}$ & & DILI & $\begin{array}{l}\text { Tired, anorexia, } \\
\text { intense itching and } \\
\text { dark brown urine }\end{array}$ & 258 & \multicolumn{2}{|c|}{ Discontinued } & $\begin{array}{l}\text { Underwent } \\
\text { orthotopic liver } \\
\text { transplantation }\end{array}$ \\
\hline O'Beirne et al. (15) & $54 / \mathrm{F}$ & $\begin{array}{l}\text { United Kingdom } \\
\text { /Brighton }\end{array}$ & Chole & estatic hepatitis & Pruritus, dark urine & 232 & \multicolumn{2}{|c|}{ Discontinued } & Normal \\
\hline Nayudu et al. (16) & $34 / \mathrm{F}$ & USA/Bronx & & DILI & $\begin{array}{c}\text { Epigastric } \\
\text { abdominal pain, } \\
\text { nausea }\end{array}$ & 458 & \multicolumn{2}{|c|}{ Discontinued } & Normal \\
\hline Larrey et al. (17) & $74 / \mathrm{F}$ & France/Nice & chole & estatic hepatitis & $\begin{array}{l}\text { Acute jaundice, } \\
\text { nausea, asthenic, } \\
\text { abdominal pain }\end{array}$ & 189 & \multicolumn{2}{|c|}{ Discontinued } & Died \\
\hline
\end{tabular}

Abbreviations: DILI, Idiosyncratic drug-induced liver injury; F, female; M, male.

pression and was prescribed fluoxetine hydrochloride capsules (20 mg per day) by her psychiatrist. She had taken it for 3-months. In addition, the patient had been diagnosed with osteoarthritis for 3-years and took celecoxib capsules when a pain attack. Lately, she got ache of double knee and had celecoxib capsules (200 mg per day) for 7-days. She denied any history of jaundice, alcoholism, smoking or drug use. On the 5th day of celecoxib treatment, reddish urine occurred. Two days later, her urine became dark brown ("coke") and she complained of severe pain in the upper abdomen. General examination revealed jaundice in the skin and sclera, but without rash. Her blood pres- sure was $135 / 85 \mathrm{mmHg}$ and axillary temperature was $36.7^{\circ} \mathrm{C}$. Liver injury and cholecystitis were diagnosed. Laboratory results showed significant damage to the liver (Table 3). Computed tomography (CT) of the abdomen showed gallstones and cholecystitis. The drugs were discontinued due to the alleged liver injury caused by fluoxetine and celecoxib. Symptomatic therapy was given, including hepatoprotection and analgesics. On the 3 rd day of the admission, she showed decreased abdominal pain but still had jaundice. On the 7th day after the admission, her jaundice subsided. On the 14th day after the admission, her jaundice was absent and some of her laboratory tests returned to 
the normal range (Table 3). Then she was discharged.

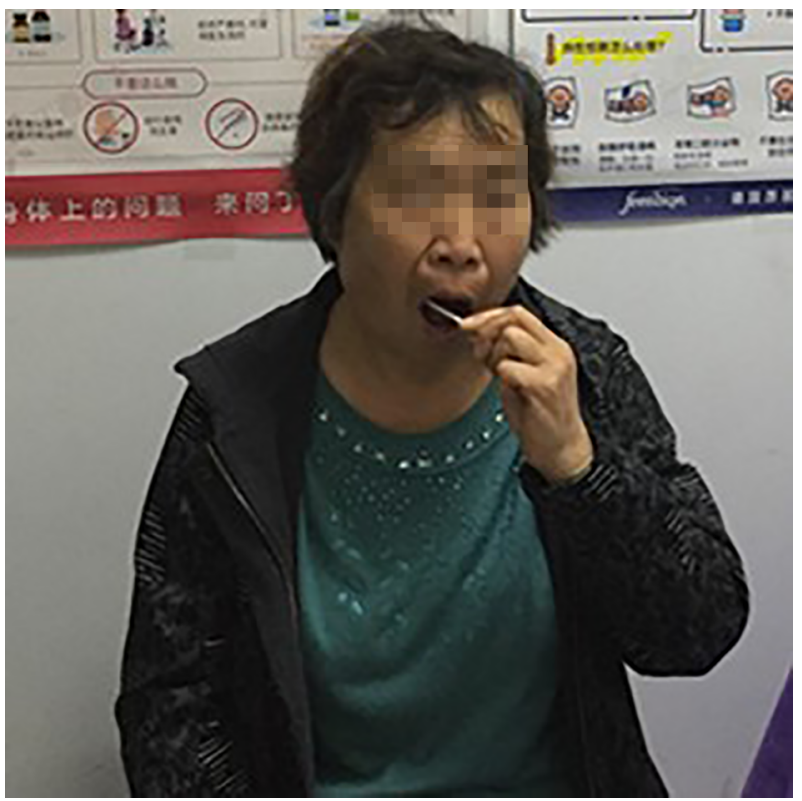

Figure 1. The patient is doing an examination

\section{Discussion}

To the best of our knowledge, this is the first case of liver injury caused by the interactions of fluoxetine and celecoxib. Our patient did not have viral hepatitis or any other liver diseases. She had taken celecoxib intermittently for 3-years and well-tolerated had taken fluoxetine 3-months with normal liver function and there were no other adverse reactions. When the two drugs were taken together, she developed signs and symptoms of liver injury. Her symptoms and signs were absent within several days after discontinuation of both drugs, and liver function tests went back to the baseline two weeks later. Because of the close association between the application of both drugs and jaundice, we suspected that her liver injury was induced by fluoxetine and celecoxib since we had excluded other factors or drugs that may cause liver injury. On the Naranjo algorithm of adverse drug reaction (ADR) probability, our case scored 6 that indicated a probable ADR (18).

The mechanism of fluoxetine and celecoxib by which caused liver injury remains unclear. There are a few assumptions. First, adverse reactions are caused by hostdependent idiosyncratic reactions or dose-dependent internal reactions. Idiosyncratic reaction is the most common type and is mediated by immune mechanisms or drug metabolism abnormalities (6). Second, fluoxetine and its principal metabolite norfluoxetine (NOR) are strong inhibitors of CYP2D6, and fluoxetine is a strong inhibitor of CYP2C19, whereas NOR is a moderately strong inhibitor of CYP3A4 in vitro and in vivo $(19,20)$. Some studies supported that CYP2C9 appears to be the principal enzyme mediating fluoxetine N-demethylation (19). Similarly, celecoxib is metabolized by CYP2C9, CYP2D6, and CYP3A4 (21), both experimental data and molecular modeling results clearly support that celecoxib is a substrate of CYP2D6 (7). These two drugs have similar metabolic pathways; it is possible that fluoxetine inhibits the metabolism of celecoxib, leading to an increase in plasma concentrations of celecoxib. The increased concentration of celecoxib may increase the risk of liver injury. Third, according to CYP Allele Nomenclature Database, there are four different distinct phenotypic groups: poor metabolizers, intermediate metabolizers, extensive metabolizers, and ultra-rapid metabolizers (22). CYP2D6*10, which reduces CYP2D6 activity, is more than $50 \%$ frequent in Chinese who are usually intermediate metabolizers (23). This genotype is characterized by its conversion of $188 \mathrm{C}$ to $\mathrm{T}$ in exon 1 , resulting in the replacement of proline 34 for serine and an unstable and less active enzyme (24). The major CYP2C19 functional alleles associated with a poorly metabolized phenotype are CYP2C19*2 and CYP2C19*3, which the latter is only found in Asian populations. CYP3A4*18 reduces the enzymatic activities and is the most common allele of CYP3A4 gene during Chinese with a frequency of $1 \%$ (21). CYP2C $9 * 13$ also can significantly decrease CYP2C9 activities but has been found in Chinese with extremely low frequency (25). Maybe this patient has hepatic enzyme deficiency cause higher plasma concentrations and clinical toxicities of therapeutic doses. Forth, the long half-life time of both fluoxetine and NOR, however, can cause pharmacological interactions with celecoxib, since plasma levels can be high even several weeks after discontinuation of the therapy. The inhibitive role may last for a long time after stopping fluoxetine since its long half-life (8 days) and NOR (19.3 days) (26).

In sum, liver injury is still a rare adverse reaction from the interactions of fluoxetine and celecoxib. It is important for clinicians to pay great attention to liver injury resulting from the combination of fluoxetine and celecoxib, or combinations of other inhibitors and substrates of similar metabolic pathways.

\section{Footnotes}

Conflict of Interests: The authors declare that they have no conflict of interests. 


\begin{tabular}{|c|c|c|c|c|c|c|c|}
\hline Date & ALT, U/L & AST, U/L & DBIL, $\mu \mathrm{mol} / \mathbf{L}$ & TBIL, $\mu \mathrm{mol} / \mathrm{L}$ & GGT, U/L & URO & BLD \\
\hline Day 1 & 536.81 & 342.53 & 38.89 & 55.47 & 472.19 & $2+$ & $1+$ \\
\hline Day 6 & 334.75 & 183.42 & 16.2 & 26.7 & 353.2 & $1+$ & $1+$ \\
\hline Day 12 & 143 & 35 & 5.8 & 16.4 & 209 & - & - \\
\hline
\end{tabular}

Abbreviations: ALT, alanine aminotransferase ( 9 - 50 U/L); AST, aspartate aminotransferase (15 - 40 U/L); DBIL, direct bilirubin ( 0 - $6.2 \mu$ mol/L); TBIL, total bilirubin (3.4 - 17.1 $\mu \mathrm{mol} / \mathrm{L})$; GGT, glutamyl aminopeptidase (10 - $60 \mathrm{U} / \mathrm{L})$; URO, urobilinogen; BLD, urine occult blood.

Ethical Considerations: The study followed the tenets of the Declaration of Helsinki, and informed consent was obtained from the patient.

Funding/Support: This research received no specific grants from any funding agencies in public, commercial or not-for-profit sectors.

\section{References}

1. Zlatkovic J, Todorovic N, Tomanovic N, Boskovic M, Djordjevic S, Lazarevic-Pasti T, et al. Chronic administration of fluoxetine or clozapine induces oxidative stress in rat liver: a histopathological study. Eur J Pharm Sci. 2014;59:20-30. doi: 10.1016/j.ejps.2014.04.010. [PubMed: 24768740].

2. Asensi-Bernardi L, Martin-Biosca Y, Escuder-Gilabert L, Sagrado S, Medina-Hernandez MJ. Fast evaluation of enantioselective drug metabolism by electrophoretically mediated microanalysis: Application to fluoxetine metabolism by CYP2D6. Electrophoresis. 2013;34(2223):3214-20. doi: 10.1002/elps.201300267. [PubMed: 24105868].

3. Liu LY, Lu Q, Wang LL. Influence of electro-acupuncture on the side effects of fluoxetine on depression patients. J Tradit Chin Med. 2009;29(4):271-4. [PubMed: 20112486].

4. Yilmaz A, Elbey B, Yazgan UC, Donder A, Arslan N, Arslan S, et al. Protective effects of caffeic acid phenethyl ester on fluoxetine-induced hepatotoxicity: An experimental study. Biomed Res Int. 2016;2016:1247191. doi: 10.1155/2016/1247191. [PubMed: 27144157]. [PubMed Central: PMC4842034].

5. Mukthinuthalapati PK, Fontana RJ, Vuppalanchi R, Chalasani N, Ghabril M. Celecoxib-induced liver injury: Analysis of Published case reports and cases reported to the food and drug administration. J Clin Gastroenterol. 2018;52(2):114-22. doi: 10.1097/MCG.0000000000000888. [PubMed: 28795997].

6. Nachimuthu S, Volfinzon L, Gopal L. Acute hepatocellular and cholestatic injury in a patient taking celecoxib. Postgrad Med J. 2001;77(910):548-50. doi: 10.1136/pmj.77.910.548. [PubMed: 11470953]. [PubMed Central: PMC1742098].

7. Siu YA, Hao MH, Dixit V, Lai WG. Celecoxib is a substrate of CYP2D6: Impact on celecoxib metabolism in individuals with CYP2C9*3 variants. Drug Metab Pharmacokinet. 2018;33(5):219-27. doi: 10.1016/j.dmpk.2018.06.001. [PubMed:30219715].

8. Johnston DE, Wheeler DE. Chronic hepatitis related to use of fluoxetine. Am J Gastroenterol. 1997;92(7):1225-6. [PubMed: 9219808].

9. Agrawal R, Almoghrabi A, Attar BM, Gandhi S. Fluoxetine-induced Stevens-Johnson syndrome and liver injury. J Clin Pharm Ther. 2019;44(1):115-8. doi: 10.1111/jcpt.12760. [PubMed: 30296343].

10. Cai Q, Benson MA, Talbot TJ, Devadas G, Swanson HJ, Olson JL, et al. Acute hepatitis due to fluoxetine therapy. Mayo Clin Proc. 1999;74(7):692-4. doi:10.4065/74.7.692. [PubMed: 10405699].

11. Grieco A, Miele L, Giorgi A, Civello IM, Gasbarrini G. Acute cholestatic hepatitis associated with celecoxib. Ann Pharmacother. 2002;36(12):1887-9. doi: 10.1345/aph.1C110. [PubMed: 12452750].
12. Galan MV, Gordon SC, Silverman AL. Celecoxib-induced cholestatic hepatitis. Ann Intern Med. 2001;134(3):254. doi: 10.7326/0003-4819-134 3-200102060-00028. [PubMed: 11177350].

13. Alegria P, Lebre L, Chagas C. Celecoxib-induced cholestatic hepatotoxicity in a patient with cirrhosis. Ann Intern Med. 2002;137(1):75. doi: 10.7326/0003-4819-137-1-200207020-00030. [PubMed: 12093262].

14. El Hajj II, Malik SM, Alwakeel HR, Shaikh OS, Sasatomi E, Kandil HM. Celecoxib-induced cholestatic liver failure requiring orthotopic liver transplantation. World J Gastroenterol. 2009;15(31):39379. doi: 10.3748/wjg.15.3937. [PubMed: 19701976]. [PubMed Central: PMC2731258].

15. O'Beirne JP, Cairns SR. Drug Points: Cholestatic hepatitis in association with celecoxib. BMJ. 2001;323(7303):23. doi: 10.1136/bmj.323.7303.23. [PubMed: 11440939]. [PubMed Central: PMC34328].

16. Nayudu SK, Badipatla S, Niazi M, Balar B. Cholestatic hepatitis with small duct injury associated with celecoxib. Case Rep Med. 2013;2013:315479. doi: 10.1155/2013/315479. [PubMed: 23861685]. [PubMed Central: PMC3687603].

17. Larrey E, Patouraux S, Spreux A, Canivet CM, Piche T, Tran A, et al Fatal cholestatic hepatitis after a single dose of celecoxib. Clin Res Hepatol Gastroenterol. 2018. doi: 10.1016/j.clinre.2018.10.007. [PubMed: 30449626].

18. Agbabiaka TB, Savovic J, Ernst E. Methods for causality assessment of adverse drug reactions: A systematic review. Drug Saf. 2008;31(1):21-37. doi: 10.2165/00002018-200831010-00003. [PubMed:18095744].

19. Schmider J, von Moltke LL, Shader RI, Harmatz JS, Greenblatt DJ. Extrapolating in vitro data on drug metabolism to in vivo pharmacokinetics: Evaluation of the pharmacokinetic interaction between amitriptyline and fluoxetine. Drug Metab Rev. 1999;31(2):545-60. doi 10.1081/DMR-100101935. [PubMed:10335452].

20. Sager JE, Lutz JD, Foti RS, Davis C, Kunze KL, Isoherranen N. Fluoxetineand norfluoxetine-mediated complex drug-drug interactions: in vitro to in vivo correlation of effects on CYP2D6, CYP2C19, and CYP3A4. Clin Pharmacol Ther. 2014;95(6):653-62. doi: 10.1038/clpt.2014.50. [PubMed: 24569517]. [PubMed Central: PMC4029899].

21. Liu R, Gong C, Tao L, Yang W, Zheng X, Ma P, et al. Influence of genetic polymorphisms on the pharmacokinetics of celecoxib and its two main metabolites in healthy Chinese subjects. Eur J Pharm Sci. 2015;79:13-9. doi:10.1016/j.ejps.2015.09.005. [PubMed: 26360837].

22. Sim SC, Ingelman-Sundberg M. The human cytochrome P450 (CYP) Allele Nomenclature website: A peer-reviewed database of CYP variants and their associated effects. Hum Genomics. 2010;4(4):278-81. [PubMed: 20511141]. [PubMed Central: PMC3525213].

23. Zhou Y, Ingelman-Sundberg M, Lauschke VM. Worldwide Distribution of cytochrome P450 alleles: A meta-analysis of populationscale sequencing projects. Clin Pharmacol Ther. 2017;102(4):688700. doi: 10.1002/cpt.690. [PubMed: 28378927]. [PubMed Central: PMC5600063].

24. Tang KF, Zhao YL, Ding SS, Wu QF, Wang XY, Shi JQ, et al. Genetic polymorphisms of CYP2D6* 10 and the effectiveness of combined tamoxifen citrate and testosterone undecanoate treatment in infertile men 
with idiopathic oligozoospermia. J Zhejiang Univ Sci B. 2015;16(3):1917. doi: 10.1631/jzus.B1400282. [PubMed: 25743120]. [PubMed Central: PMC4357368].

25. Wang Z, Wang S, Huang M, Hu H, Yu L, Zeng S. Characterizing the effect of cytochrome P450 (CYP) 2C8, CYP2C9, and CYP2D6 genetic poly- morphisms on stereoselective N-demethylation of fluoxetine. Chirality. 2014;26(3):166-73. doi: 10.1002/chir.22289. [PubMed: 24464553].

26. Otton SV, Wu D, Joffe RT, Cheung SW, Sellers EM. Inhibition by fluoxetine of cytochrome P450 2D6 activity. Clin Pharmacol Ther. 1993;53(4):401-9. doi: 10.1038/clpt.1993.43. [PubMed: 8477556]. 